DOI: https://doi.org/10.47405/mjssh.v6i9.1033

\begin{tabular}{|c|c|}
\hline & Malaysian Journal of Social Sciences and Humanities (MJSSH) \\
\hline Malaysian Journal of & Volume 6, Issue 9, September 2021 \\
\hline (Mulssh) & e-ISSN : 2504-8562 \\
\hline & $\begin{array}{l}\text { Journal home page: } \\
\text { www.msocialsciences.com }\end{array}$ \\
\hline
\end{tabular}

\title{
Keabsahan dan Kebolehpercayaan Instrumen Psikometrik Ujian Tingkah Laku Hasrat Bunuh Diri
}

\author{
Norshahira, $\mathbf{0}^{1}$, Norashida, S. $\mathbf{R}^{\mathbf{1}}$, Lukman, Z. $\mathbf{M}^{\mathbf{1}}$ \\ ${ }^{1}$ Fakulti Sains Sosial Gunaan, Universiti Sultan Zainal Abidin (UNISZA) \\ Correspondence: Norshahira, 0 (norshahira_osman@yahoo.com)
}

\begin{abstract}
Abstrak
Instrumen Ujian Tingkah Laku Hasrat Bunuh Diri (SIBA) dihasilkan untuk mengukur tahap tingkah laku hasrat bunuh diri dalam kalangan penagih di Malaysia bagi membantu mereka dan kerajaan mengurangkan kes bunuh diri di negara ini. Kajian ini bertujuan menghasilkan bukti empirikal mengenai keabsahan dan kebolehpercayaan instrumen SIBA dengan menggunakan model pembinaan instrumen daripada Miller et al. (2013), yang telah diubahsuai. Pembinaan instrumen itu dibuat berdasarkan satu kerangka konseptual yang dibentuk secara hipotetikal dan hasil kajian pengkajipengkaji terdahulu yang telah membuat penelitian secara mendalam tentang hubungan penagihan dadah dengan tingkah laku hasrat bunuh diri. Instrumen ini mengandungi empat komponen iaitu konflik interpersonal, kecelaruan emosi, kemurungan, dan putus harapan. Setiap komponen SIBA mengandungi 10 item dan jumlah keseluruhannya ialah 40 item. Analisis Faktor Eksploratori (Exploratory Factor Analysis - EFA) digunakan untuk menentukan keabsahan dan kebolehpercayaan setiap item dalam komponen-komponen tersebut. Dalam hal ini, seramai 123 penagih yang dirawat di Cure \& Care Rehabilitation Centre (CCRC) Besut, Terengganu dipilih sebagai responden kajian untuk pengujian instrumen ini. Kajian ini mendapati bahawa muatan faktor untuk setiap item adalah dalam julat 0.45 hingga 0.87 dan nilai kebolehpercayaan (alpha) pula adalah dalam julat 0.83-0.90. Dapatan kajian ini jelas menunjukkan instrumen ini mempunyai keabsahan dan kebolehpercayaan yang tinggi dan boleh diguna pakai dalam mengukur tahap tingkah laku hasrat bunuh diri dalam kalangan penagih dadah di CCRC, Besut. Secara keseluruhannya, analisis keabsahan dan kebolehpercayaan ini adalah penting bagi memastikan penghasilan instrumen SIBA ini boleh diguna pakai untuk mengukur tahap tingkah laku hasrat bunuh diri dalam kalangan penagih dadah yang berkualiti dan bermakna.
\end{abstract}

Kata kunci: SIBA, bunuh diri, instrumen, keabsahan dan kebolehpercayaan

\section{Validity and Reliability of the Psychometric Instruments Suicidal Ideation Behaviour Assessment}

\begin{abstract}
Suicidal Ideation Behavior Assessment (SIBA) instrument was developed to measure the level of suicidal behavior among addicts in Malaysia to help them and the government reduce suicide cases in the country. This study aimed to generate empirical evidence on the validity and reliability of the SIBA instrument by using the instrument construction model from Miller et al. (2013), which has been modified. The construction of the instrument was made based on a hypothetically formed conceptual framework and the results of studies of previous researchers who have conducted in-depth research on the relationship of drug addiction with suicidal ideation behavior. The instrument contains four
\end{abstract}


components namely interpersonal conflict, emotional disorder, depression, and hopelessness. Each SIBA component contains 10 items and the total is 40 items. Exploratory Factor Analysis (EFA) is used to determine the validity and reliability of each item in the components. In this case, a total of 123 addicts treated at the Cure \& Care Rehabilitation Center (CCRC) Besut, Terengganu were selected as study respondents for testing this instrument. This study found that the factor loading for each item was in the range of 0.45 to 0.87 and the reliability value (alpha) was in the range of $0.83-0.90$. The findings of this study clearly show that this instrument has high validity and reliability and can be used in measuring the level of suicidal behavior among drug addicts in CCRC, Besut. Overall, this analysis of validity and reliability is important to ensure that the production of this SIBA instrument can be applied to measure the level of suicidal ideation behavior among drug addicts with quality and meaningful.

Keywords: SIBA, suicidal, instrument, validity and reliability

\section{Pengenalan}

Masalah penagihan dadah dikenal pasti menjadi faktor utama dan berisiko tinggi yang berkaitan dengan tingkah laku hasrat bunuh diri di seluruh dunia (UNODOC, 2014). Individu yang menggunakan dadah atau dikenali sebagai penagih dadah berisiko lebih tinggi untuk bunuh diri daripada mereka yang tidak menggunakan dadah (Inman et al., 2011; Taylor, 2018; NSDUH, 2018). Laporan WHO (2019), mendedahkan masalah bunuh diri ini adalah fenomena global, yang tersebar luas berlaku di negara berpendapatan rendah dan sederhana. Peralihan dari tingkah laku bunuh diri ke arah bunuh diri sebenar sering berlaku secara impulsif sebagai reaksi terhadap psikososial seseorang (Bilsen, 2018). Laporan WHO (2017), pada tahun 2015, dianggarkan seramai 7888,000 bunuh diri berlaku di seluruh dunia. Hal ini menyebabkan negara Sri Lanka berada di kedudukan negara yang mempunyai kadar bunuh diri tertinggi iaitu sebanyak 34.6\% daripada kadar bunuh diri setiap 100.000 penduduk diikuti dengan negara Guyana sebanyak 30\% dan Mangolia sebanyak 28\%. Pada tahun 2016 pula, kadar bunuh diri didahului oleh negara Lithuania dengan peratus bunuh diri sebanyak 31.9\%, diikuti oleh Rusia iaitu sebanyak $31 \%$, ketiga Guyana dengan catatan sebanyak 29\% (WHO, 2017). Laporan GBD Collaborative Network (2018), pada tahun 2017, negara yang mempunyai bilangan tertinggi kes bunuh diri adalah Greenland sebanyak 51.06\%, diikuti negara Lesotho sebanyak $31.72 \%$ dan diikuti negara Lithuania 27.22\%. Tambahan pula, negara Malaysia yang kini melalui arus pemodenan turut tidak terlepas daripada mengalami masalah kes bunuh diri. Laporan GBD Collaboration Network (2018) mendedahkan bahawa seramai 7.85\% kes bunuh diri berlaku untuk setiap 100,000 penduduk dikesan di Malaysia. Malaysia berada pada tangga (ranking) ke-146 dunia dalam kes bunuh diri pada tahun 2017. Berdasarkan situasi ini, satu instrumen yang boleh mengukur tahap tingkah laku hasrat bunuh diri dalam kalangan penagih di Malaysia perlu dibina bagi membantu mereka dan kerajaan mengurangkan kes bunuh diri di negara ini yang berkaitan dengan masalah penagihan dadah.

Secara khususnya, kajian ini dilaksanakan bagi mengesahkan satu instrumen yang dapat memenuhi objektif kajian di samping memberi peluang kepada penagih dadah untuk menilai tahap tingkah laku hasrat bunuh diri. Ianya juga bertujuan memberi pengesanan awal bagi memastikan mereka tidak mengambil tindakan selanjutnya yang boleh menyebabkan kematian. Pemilihan dan pengesahan instrumen yang dibina ini dapat membantu penagih dadah membuat refleksi kendiri terhadap apa yang telah dialami dan dilalui dalam persekitaran mereka. Oleh itu, instrumen yang dibina ini juga boleh dijadikan sebagai sumber rujukan pihak yang terlibat terutama kerajaan dalam membantu perancangan strategi untuk menangani kes-kes bunuh diri dalam kalangan penagih dadah dengan lebih berkesan. Hasil dapatan kajian ini membolehkan penagih dadah lebih memahami dan mengetahui tahap tingkah laku hasrat bunuh diri yang dialaminya. Selain itu juga, pihak CCRC juga dapat mengenal pasti masalah yang mungkin dihadapi semasa keberadaan dalam persekitaran di CCRC berkenaan. Instrumen ini diharapkan dapat dijadikan sebagai panduan dan rujukan bagi meninjau sejauh mana tahap tingkah laku hasrat bunuh diri dapat dicapai dengan jayanya secara optimum pada keadaan semasa bersesuaian dengan sasaran dan hala tuju sesebuah institusi pemulihan terutama CCRC. Hasil penyelidikan ini diharapkan berperanan dalam pengurangan kematian yang berkaitan dengan bunuh diri. Oleh itu, ianya 
perlu ada pendekatan pencegahan dan strategi intervensi untuk masalah ini (Conner et al., 2014; Taylor, 2018; SAMHSA, 2015).

\section{Sorotan Literatur}

Tanpa kita sedar bahawa perkembangan tingkah laku hasrat bunuh diri ini semakin berleluasa di peringkat global (Lima et al., 2010; WHO, 2017; GBD, 2018). Oleh itu, kes ini menjadi sogokkan dan paparan yang utama dengan pelbagai cerita mengenai gejala tingkah laku bunuh diri dan memberi gambaran sekali gus betapa seriusnya kes bunuh diri. Oleh hal demikian, instrumen Tingkah Laku Hasrat Bunuh Diri (SIBA) ini dibina bagi mengesan tahap tingkah laku hasrat bunuh diri dalam kalangan penagih dadah berdasarkan situasi di Malaysia. Berdasarkan instrumen ini, tingkah laku hasrat bunuh diri ini merujuk kepada idea bunuh diri iaitu pemikiran yang serius terhadap bunuh diri yang mungkin membawa kepada bentuk tingkah laku bunuh diri yang sangat bahaya dengan bertujuan untuk mati (David \& Tanya, 2009). Pembinaan instrumen itu dibuat berdasarkan satu kerangka konseptual yang dibentuk daripada hasil kajian pengkaji-pengkaji terdahulu mengenai hubungan penagihan dadah dengan tingkah laku hasrat bunuh diri. Instrumen ini mengandungi empat komponen iaitu konflik interpersonal, kecelaruan emosi, kemurungan, dan putus harapan. Bagi komponen utama iaitu konflik interpersonal merupakan perasan penagih yang mempunyai perasaan negatif diri sendiri terhadap orang lain dan perasaan negatif orang terhadap diri sendiri. Ia merupakan interaksi antara individu yang saling bergantung di mana individu itu mempunyai perselisihan pendapat dan kepentingan untuk menentang, ketidakserasian, gangguan atau dikenali sebagai perasaan negatif (Bao et al., 2016; Buchman et al., 2017; Lams et al., 2014). Konflik interpersonal merujuk kepada aspek hubungan antara seorang individu dengan orang lain. Ini termasuklah bagaimana seseorang itu menguruskan tingkah laku dan pemikiran ketika berhadapan dengan diri atau orang sekeliling (Quilty et al., 2013; Van Orden et al. 2010; Dragisic et al. 2015).

Kecelaruan emosi merupakan gangguan mental yang mempunyai hubung kait atau hubungan terhadap tingkah laku atau psikologi individu yang mana individu tersebut tidak dapat mengawal mental sehingga mempunyai tingkah laku hasrat bunuh diri (WHO, 2017). Individu dalam keadaan emosi yang tidak stabil menyebabkan mereka mengalami gangguan mental, gangguan psikiatri dan psikologi yang dikaitkan dengan kesedihan. Kecelaruan emosi akan mendatangkan kemudaratan kepada fungsi tubuh badan dan mental para penagih. Oleh itu, kecelaruan emosi adalah gabungan beberapa pemikiran, tingkah laku dan hubungan yang tidak normal terhadap orang lain (Brent, 1995; Schutte et al., 2007). Penagih dadah yang mengalami ketidakstabilan emosi akan mewujudkan perasaan marah, berdukacita, kecewa, cemburu, rasa bersalah, tiada menaruh sebarang harapan yang tinggi dalam hidup, tidak mampu bergembira seperti orang lain dan sering berasa lesu (Sawaya et al., 2015; Gallagher \& Miller, 2018). Dalam kajian ini, kecelaruan emosi berlaku apabila penagih dadah menghadapi resah dan kecewa. Keadaan resah boleh menyebabkan penagih berasa tidak tenang setiap bangun pagi, kehidupan yang membosankan, perasaan sedih yang tidak terkawal, mengalami mimpi ngeri dan tidak cukup tidur, letih serta bingung apabila berhadapan dengan masalah. Bagi keadaan kecewa pula, penagih sering marah kepada diri sendiri kerana tidak dapat selesaikan masalah yang dialami, emosi mudah terganggu, sering mengalami sakit kepala, sering mengamuk dan pernah dinasihati oleh doktor untuk mengambil ubat tertentu atau menjalani rawatan kesihatan mental.

Kemurungan pula berlaku apabila penagih dadah mengalami keadaan yang rumit mengganggu personaliti atau tekanan (Oquendo et al., 2014; Dragisic et al., 2015; Ugwuoke et al., 2016: Ghaffari et al. 2012; Pedrelli et al. 2011; Evren et al., 2011). Ia memberi kesan kesihatan emosi yang membahayakan. Kemurungan ini merujuk kepada keadaan penagih dadah sering merasa lesu, sering merasa bersalah, pernah mengambil dadah secara berlebihan, mengabaikan kesihatan fizikal, suka bersendirian, hilang minat melakukan aktiviti yang biasa dilakukan, suka bercakap sendirian, mengalami fikiran yang serabut, tekanan emosi dalam tempoh yang panjang dan sering merujuk kepada hospital kerana berkelakuan aneh. Oleh hal demikian, penagih akan menggunakan dadah kerap kerana untuk membantu mereka menghilangkan kemurungan dalam diri mereka (Wong et al., 2013; Youssef et al., 2016). 
Bagi putus harapan merupakan keadaan apabila penagih dadah mula menganggap dirinya tidak mempunyai masa hadapan sehingga wujudnya perasaan bunuh diri (Alloy et al., 2012). Oleh itu, individu mempunyai sifat putus harapan melihat masa depan mereka secara lebih negatif (Jager et al., 2014; Boduszek \& Dhingra, 2016; Lliceto \& Fino, 2015). Putus harapan adalah tahap seseorang percaya bahawa dirinya mempunyai masa depan yang gelap dan suram. Seseorang yang merasakan dia mempunyai masa depan yang gelap dan gagal menunjukkan bahawa individu tersebut mempunyai tingkah laku yang salah. Hal ini menunjukkan bahawa tahap putus harapan yang lebih tinggi yang ada dalam diri seseorang mampu meningkatkan kecenderungan seseorang ke arah tingkah laku hasrat bunuh diri (Briere, 2012; O'Connor et al., 2014; Jenny et al., 2015).

Keadaan ini jika tidak ditangani boleh memberikan kesan buruk terhadap keupayaan negara dalam membanteras tingkah laku bunuh diri dalam kalangan penagih dadah. Mengambil kira permasalahan yang telah dibincangkan, timbul persoalan iaitu sejauh mana pelaksanaan intervensi yang dirancang dapat diterima oleh kerajaan dalam membantu tingkah laku bunuh diri dalam negara Malaysia. Justeru, usaha membangunkan instrumen ini menepati keperluan keadaan semasa, di samping sebagai sumbangan kecil pengkaji dalam merungkai keadaan sebenar pelaksanaan instrumen yang dibina. Oleh itu, instrumen ini berguna sebagai petunjuk kepada pihak berkepentingan dalam menangani permasalahan yang berlaku dalam negara.

\section{Tujuan Kajian}

Kajian ini bertujuan untuk menguji keabsahan dan kebolehpercayaan instrumen SIBA dalam kalangan penagih dadah di CCRC, Besut.

\section{Metod Kajian}

Kajian ini adalah merupakan kajian kuantitatif iaitu reka bentuk kajian jenis tinjauan. Dalam kajian ini, reka bentuk tinjauan dipilih kerana penyelidik membina instrumen bagi ujian tingkah laku hasrat bunuh diri. Kaedah ini mempunyai kelebihan iaitu instrumen boleh ditadbirkan secara terus kepada responden dan menjimatkan masa, tenaga dan kewangan (Creswell, 2011). Pengkaji menggunakan teknik kajian persampelan bertujuan kerana maklumat yang dikumpulkan dapat memberi gambaran kasar tentang fenomena yang wujud dalam sesuatu populasi kajian dan membantu penyelidik meneroka kajian yang lebih mendalam (Fraenkel \& Wallen, 2009). Penyelidikan ini telah dilakukan terhadap penagih dadah lelaki yang menjalani pemulihan di CCRC, Besut di negeri Terengganu. Penyelidik telah mengedarkan borang soal selidik melibatkan 123 responden. Lokasi kajian ditentukan dengan mengambil kira kesesuaian instrumen agar relevan ditadbir kepada penagih dadah di CCRC, Besut. Sampel kajian adalah terhad kepada penagih dadah di CCRC, Besut sahaja. Sebelum pengumpulan data dimulakan, penyelidik telah mendapatkan kebenaran bertulis daripada Ketua Pengarah (Agensi Antidadah Kebangsaan)_AADK. Teknik kajian yang digunakan adalah melalui pengedaran soal selidik kepada responden dan ditadbir menggunakan kertas dan pencil. Penganalisisan data dalam kajian ini dilakukan dengan menggunakan Statistical Package for the Social Sciences (SPSS version 12.0).

\section{Instrumen Kajian}

Instrumen kajian yang dibina ini mempunyai dua bahagian iaitu bahagian pertama meliputi latar belakang responden dan bahagian kedua berkenaan penilaian ujian tingkah laku hasrat bunuh diri. Bahagian kedua meliputi empat komponen iaitu konflik interpersonal, kecelaruan emosi, kemurungan dan putus harapan. Komponen dalam instrumen kajian ini dibentuk berdasarkan kepada satu kerangka konseptual yang dibentuk secara hipotetikal dan hasil kajian pengkaji-pengkaji terdahulu. Soal selidik yang dibina menggunakan skala Likert empat mata iaitu Sangat Tidak Setuju (0), Tidak Setuju (1), Setuju (2) dan Sangat Setuju (3). Pemurnian instrumen yang dibina dalam kajian ini melalui proses penyemakan dan pengesahan oleh pakar dalam bidang yang berkaitan. 


\section{Prosedur Pembangunan Instrumen}

Dalam konteks kajian ini pengkaji mengaplikasikan prosedur mengikut model pembinaan instrumen daripada Miller et al. (2013), yang telah diubahsuai iaitu:

\section{Peringkat pertama- Mentakrifkan komponen, menentukan tujuan dan sasaran instrumen}

Terdapat empat langkah yang digunakan dalam peringkat pertama dalam pembinaan instrumen SIBA. Langkah pertama ialah mengkaji literatur yang berkaitan dengan tingkah laku hasrat bunuh diri dalam kalangan penagih dadah. Literatur ini meliputi jurnal dan artikel kajian-kajian terdahulu yang dijalankan sama ada dari dalam mahupun di luar negara. Langkah ini penting untuk mengenal pasti komponen utama yang terdapat dalam tingkah laku hasrat bunuh diri yang dalam kalangan penagih dadah. Langkah kedua ialah mengkaji komponen-komponen atau item-item yang sesuai dalam instrumen yang telah dibina oleh pengkaji lepas. Hal ini boleh membantu dalam pembinaan instrumen sekiranya terdapat komponen atau item yang bersesuaian, ia boleh diubahsuai mengikut kesesuaian konteks kajian. Seterusnya, langkah ketiga melibatkan sesi perbincangan bersama pensyarah-pensyarah yang berpengalaman bagi memperoleh maklumat, pendapat dan idea berkaitan dengan tingkah laku hasrat bunuh diri yang utama dalam kalangan penagih dadah. Ini bagi menguatkan lagi dapatan bagi pembinaan komponen utama. Langkah keempat pula melibatkan pemilihan dan penentuan komponen utama dalam tingkah laku hasrat bunuh diri berdasarkan pemerolehan sebelumnya (tinjauan literatur, instrumen sedia ada dan perbincangan dengan pakar). Sehubungan dengan itu, komponen yang telah ditentukan sebagai mewakili aspek yang berkaitan dengan tujuan asal pembinaan instrumen iaitu komponen konflik interpersonal, kecelaruan emosi, kemurungan dan putus harapan.

\section{Peringkat ke dua- Pembinaan Item Instrumen}

Peringkat kedua pula melibatkan pembinaan item instrumen. Pembinaan item ini dilakukan merujuk kepada kajian-kajian lepas untuk dimasukkan sebagai item dalam instrumen yang dibina. Pembinaan item instrumen dalam kajian ini hendaklah mempunyai definisi yang jelas dan sesuai mengikut persekitaran dan tidak lari daripada tujuan asal kajian yang hendak dikaji. Oleh hal demikian, item-item dibina berdasarkan literatur dan perbincangan untuk setiap komponen yang telah dikenal pasti. Hasilnya 40 item telah dibina untuk 4 komponen yang relevan telah ditentukan. Jadual 1 menunjukkan bilangan komponen dan item instrumen SIBA.

Jadual 1: Bilangan Komponen dan Item Instrumen SIBA

\begin{tabular}{lll}
\hline Komponen & Sub-Komponen & Bilangan Item \\
\hline Konflik Interpersonal & Perasaan negatif diri sendiri kepada orang lain & 5 \\
& Perasaan negatif orang lain kepada diri sendiri & 5 \\
Kecelaruan Emosi & Resah & 5 \\
& kecewa & 5 \\
Kemurungan & Kemurungan & 10 \\
Putus Harapan & Putus Harapan & 10 \\
\hline
\end{tabular}

\section{Peringkat ke Tiga-Semakan Item Instrumen}

Langkah seterusnya adalah semakan daripada beberapa orang pakar dalam bidang pengajian yang berkaitan. Ianya berkait dengan percubaan dan ramalan dalam menimal satu alat pengukuran untuk mengenal pasti tahap tingkah laku hasrat bunuh diri dalam kalangan penagih dadah bersesuaian dalam konteks di Malaysia. Oleh itu, selepas instrumen telah siap direka bentuk, pengkaji menghantar ke pakar untuk mendapatkan maklum balas terhadap kesahan kandungan instrumen. Instrumen dinilai oleh panel pakar dalam bidang yang sesuai terutama dari segi bahasa. Kajian ini telah membuat kesahan kandungan untuk melihat maklum balas daripada pakar. Ianya dilakukan semakan ke atas item-item instrumen yang telah dinilai oleh pakar untuk memastikan instrumen sah untuk digunakan. kajian ini merujuk kepada lapan pakar dalam pelbagai bidang iaitu bidang psikomektrik, analisis, psikologi, 
analisis validity, pembinaan item dan pembinaan item kepulihan. Mereka terdiri daripada pensyarahpensyarah Universiti Sultan Zainal Abidin (UniSZA), Universiti Malaysia Terengganu (UMT) dan Universiti Pendidikan Sultan Idris (UPSI). Pengubahsuaian dilakukan secara berulang kali bagi setiap item yang dihasilkan supaya item dapat diukur sejajar dengan objektif kajian. Setiap item yang dibina mengikut penetapan struktur format yang betul iaitu setiap item dipastikan mengikut arahan yang menyeluruh dan kejelasan makna (Frankeal \& Wallen, 2006; Pallant, 2010). Setiap struktur item diselarikan mengikut kehendak kajian seperti objektif kajian, pengolahan dari segi penggunaan bahasa, keupayaan item untuk mengukur komponen kajian dan ketiadaan masalah pengulangan item. Antara kesukaran dalam membentuk item instrumen SIBA iailah proses pembinaan item ini mengambil masa yang lama kerana segala teguran serta komen yang diberikan diterima daripada pakar dibaiki dan diguna pakai. Hal ini kerana, ianya untuk memantapkan kualiti dari segi bahasa, format dan kandungan setiap item. Pakar-pakar ini telah bersetuju untuk mengesahkan instrumen setelah menyemak item-item yang disediakan ini menggunakan borang semakan item. Instrumen yang telah disemak oleh pakar ini kemudiannya dianalisis menggunakan Formula daripada Lawshe's Bagi Nisbah Kesahan Kandungan (CVR). Hasilnya taburan keseluruhan item berjaya dikekalkan iaitu sebanyak 40 item yang merangkumi komponen konflik interpersonal (10 item) dikekalkan, komponen kecelaruan emosi (10 item), dikekalkan komponen kemurungan (10 item) dikekalkan dan juga komponen putus harapan (10 item) dikekalkan.

\section{Peringkat ke empat: Kajian Rintis}

Langkah ketiga pula adalah menjalankan kajian rintis kepada 40 responden yang dipilih di CCRC, Besut. Kajian rintis ini dijalankan bagi menentukan nilai kebolehpercayaan instrumen kajian yang telah dibina. Kebolehpercayaan instrumen adalah penting untuk dijalankan untuk mengukur tahap ketekalan item dalam suatu komponen yang dibina. Nilai kebolehpercayaan menghampiri 1.00 menunjukkan bahawa instrumen yang dibina mempunyai kebolehpercayaan yang tinggi (Bond \& Fox, 2015). Oleh itu, analisis dapatan kajian rintis yang dijalankan menunjukkan bahawa nilai kebolehpercayaan Cronbach's Alpha bagi empat komponen adalah antara julat 0.83 hingga 0.90 dan bagi keseluruhan instrumen menunjukkan nilai kebolehpercayaan 0.87. (lihat Jadual 2). Berdasarkan nilai Cronbach's Alpha yang diperoleh, didapati Instrumen SIBA mempunyai nilai kebolehpercayaan yang tinggi dan membuktikan bahawa item dalam instrumen mempunyai ketekalan dalaman yang baik dengan tahap konsistensi yang tinggi.

Jadual 2: Nilai Kebolehpercayaan bagi Kajian Rintis

\begin{tabular}{lll}
\hline Komponen & $\begin{array}{l}\text { Nilai Kebolehpercayaan } \\
\text { Kajian Rintis }\end{array}$ & $\begin{array}{l}\text { Interpretasi } \\
\text { Kebolehpercayaan }\end{array}$ \\
\hline Konflik Interpersonal & 0.88 & Sangat Baik dan diterima \\
Kecelaruan Emosi & 0.88 & Sangat Baik dan diterima \\
Kemurungan & 0.83 & Sangat Baik dan diterima \\
Putus Harapan & 0.90 & Sangat Baik dan diterima \\
Nilai Kebolehpercayaan Instrumen & 0.87 & Sangat Baik dan diterima \\
\hline
\end{tabular}

\section{Peringkat ke lima: Keabsahan Dan Kebolehpercayaan Instrumen (Kajian Sebenar)}

Peringkat kelima terdiri daripada dua langkah. Langkah pertama ialah melibatkan pentadbiran instrumen yang telah dibina pada sampel yang lebih besar bagi meningkatkan lagi kesahan dan kebolehpercayaan instrumen dan membolehkannya diguna pakai dalam menilai tingkah laku hasrat bunuh diri dalam kalangan penagih dadah. Bagi kajian sebenar pemilihan tempat responden adalah sama dengan pemilihan tempat responden bagi kajian rintis. Seramai 130 responden berada di CCRC, Besut, Terengganu tetapi hanya 123 sahaja yang mengambil bahagian. Seramai 7 orang penghuni tidak mengambil bahagian berada dalam pengawasan kerana terlibat dengan kesalahan dalam pusat pemulihan tersebut. Langkah kedua pula melibatkan analisis faktor. Analisis faktor dijalankan dengan tujuan untuk mengesahkan komponen-komponen yang telah dipilih dalam instrumen. Terdapat beberapa kaedah yang boleh digunakan untuk mendapatkan kesahan sesuatu instrumen yang dibina antaranya ialah kesahan kandungan, kesahan kriteria dan kesahan komponen. Mengikut kajian oleh Nunally 
(1967) kesahan komponen adalah lebih tepat digunakan untuk mengesahkan instrumen yang dibina. Oleh itu, kaedah Analisis Faktor Penerokaan (EFA) digunakan bagi mengesahkan pembinaan komponen dan item yang telah dibentuk dalam instrumen SIBA.

\section{Hasil Kajian}

Keputusan Analisis Faktor Penerokaan (EFA) ke atas setiap item menggunakan kaedah Extraction of Principal Component dengan Varimax Rotation untuk mengukur item dalam komponen SIBA. Nilai signifikan bagi sukatan kecukupan pensampelan Kaiser-Meyer-Olkin (KMO) dan nilai Ujian Kesferaan Bartlett diteliti dengan baik sebelum analisis faktor dilakukan. Kaiser (1974) menetapkan nilai KMO $>0.5$ dan nilai ujian kesferaan Bartlett yang cukup besar menunjukkan suatu data memenuhi syarat kebolehfaktoran. Keputusan Analisis Faktor Penerokaan (EFA)Analisis faktor dijalankan menggunakan kaedah Extraction of Principal Component dengan Varimax Rotation ke atas setiap item yang mengukur komponen penerimaan pelaksanaan SIBA. Nilai signifikan bagi sukatan kecukupan pensampelan Kaiser-Meyer-Olkin (KMO) dan nilai Ujian Kesferaan Bartlett diteliti sebelum analisis faktor dijalankan. Oleh itu, nilai KMO $>0.5$ ke atas dan nilai ujian kesferaan Bartlett yang cukup besar menunjukkan suatu data memenuhi syarat kebolehfaktoran (Kaiser, 1974). Walau bagaimanapun, menurut Hair et al. (2010), nilai faktor 0.3 dan 0.4 ke atas menunjukkan bahawa item tersebut masih boleh diterima dan dipertimbangkan untuk kajian yang dijalankan. Keputusan analisis dalam Jadual 2 menunjukkan nilai signifikan bagi ujian KMO dan Ujian Kesferaan Bartlett bagi kajian ini. Hasil bagi kajian ini menunjukkan data telah memenuhi syarat kebolehfaktoran untuk melaksanakan analisis faktor. Keputusan analisis dinyatakan dalam Jadual 3 menunjukkan nilai signifikan bagi ujian KMO dan Ujian Kesferaan Bartlett.

Jadual 3: Nilai Kaiser Meyer Olkin dan Signifikan Komponen

\begin{tabular}{llllll}
\hline Komponen & $\begin{array}{l}\text { Kaiser-Meyer-Olkin } \\
\text { Measure of }\end{array}$ & Bil Item & \multicolumn{3}{l}{ Bartlett's Test of Sphericity } \\
\cline { 5 - 6 } & Sampling Adequacy & & $\begin{array}{l}\text { Approx. Chi- } \\
\text { Square }\end{array}$ & Df & Sig. \\
& 0.82 & 10 & 230.60 & 45 & 0.00 \\
Konflik Interpersonal & 0.73 & 10 & 212.53 & 45 & 0.00 \\
Kecelaruan Emosi & 0.74 & 10 & 210.46 & 45 & 0.00 \\
Kemurungan & 0.77 & 10 & 288.18 & 45 & 0.00 \\
Putus Harapan & & & &
\end{tabular}

Seterusnya adalah melihat kepada nilai muatan faktor bagi setiap item dalam setiap komponen SIBA bagi kajian sebenar. Jadual 4 hingga Jadual 7 menunjukkan bilangan item bagi setiap komponen telah berjaya diekstrak. Secara keseluruhannya, muatan faktor setiap item berada dalam julat 0.45 hingga 0.87 menunjukkan nilai muatan faktor sangat baik secara praktikal dalam menentukan faktor sesuatu skala pengukuran.

Jadual 4: Nilai Muatan Faktor Setiap Item Bagi Komponen Konflik Interpersonal

\begin{tabular}{llll}
\hline Item & & \multicolumn{2}{c}{ Komponen } \\
\cline { 3 - 4 } & & $\mathbf{1}$ & $\mathbf{2}$ \\
\hline 7 & Saya berasa orang di sekeliling sangat membenci diri saya & 0.81 & \\
9 & Saya berasa orang di sekeliling sering mengkhianati saya. & 0.81 & \\
10 & Saya berasa orang di sekeliling sering menyalahkan saya terhadap & 0.79 & \\
& sesuatu perkara yang berlaku & & \\
5 & Saya berasa diri saya sering menjadi mangsa penganiayaan orang di & 0.70 & \\
& Sekeliling. & & \\
8 & Saya berasa orang di sekeliling sering menjauhkan diri daripada saya. & 0.64 & 0.80 \\
1 & Saya berasa diri saya banyak menyusahkan orang di sekeliling. & & 0.78 \\
3 & Saya berasa diri saya terlalu hina berbanding orang di sekeliling & & 0.7 \\
4 & Saya berasa diri saya tidak berguna kepada orang lain. & & 0.50 \\
2 & Saya berasa diri saya sering bernasib malang berbanding orang di & & \\
\hline
\end{tabular}


$6 \quad$ Saya berasa orang di sekeliling tidak mengambil berat tentang diri saya.

Jadual 5: Nilai Muatan Faktor Setiap Item Bagi Komponen Kecelaruan Emosi

\begin{tabular}{clll}
\hline Item & & \multicolumn{2}{l}{ Komponen } \\
\cline { 3 - 3 } $\mathbf{1 6}$ & $\begin{array}{l}\text { Saya sering marah kepada diri sendiri apabila tidak dapat } \\
\text { menyelesaikan sesuatu masalah yang dihadapi. }\end{array}$ & $\mathbf{0 . 8 3}$ \\
$\mathbf{1 7}$ & $\begin{array}{l}\text { Emosi saya mudah terganggu atau terusik degan parah apabila } \\
\text { mengalami tekanan hidup. }\end{array}$ & $\mathbf{0 . 7 6}$ & \\
$\mathbf{1 5}$ & $\begin{array}{l}\text { Saya sering tidak cukup tidur, letih dan kebingungan apabila } \\
\text { berhadapan dengan sesuatu masalah yang berat. }\end{array}$ & $\mathbf{0 . 7 1}$ & \\
$\mathbf{1 2}$ & $\begin{array}{l}\text { Saya sering berasa kehidupan saya tidak bermakna dan } \\
\text { membosankan. }\end{array}$ & $\mathbf{0 . 6 7}$ & \\
$\mathbf{1 1}$ & $\begin{array}{l}\text { Saya sering berasa tidak tenang (serabut setiap kali bangun pagi. } \\
\mathbf{1 3}\end{array}$ & $\mathbf{0 . 5 8}$ & $\mathbf{0 . 4 9}$ \\
$\mathbf{1 9}$ & $\begin{array}{l}\text { Saya sering mengalami perasaan sedih yang tidak terkawal. } \\
\text { mengalami masalah atau tekanan hidup }\end{array}$ & $\mathbf{0 . 8 6}$ \\
$\mathbf{2 0}$ & $\begin{array}{l}\text { Saya pernah dinasihati oleh doktor untuk mengambil ubat tertentu } \\
\text { atau menjalani rawatan kesihatan mental. }\end{array}$ & $\mathbf{0 . 8 1}$ \\
$\mathbf{1 8}$ & $\begin{array}{l}\text { Saya sering mengalami sakit kepala, sakit leher atau mual sekurang- } \\
\text { kurangnya sebulan sekali. }\end{array}$ & $\mathbf{0 . 6 9}$ \\
$\mathbf{1 4}$ Saya sering mengalami mimpi ngeri atau buruk. & $\mathbf{0 . 5 1}$ \\
\hline
\end{tabular}

Jadual 6: Nilai Muatan Faktor Setiap Item Bagi Komponen Kemurungan

\begin{tabular}{lllll}
\hline Item & & Komponen & \\
\cline { 3 - 4 } & & $\mathbf{1}$ & $\mathbf{2}$ \\
\hline 27 & Saya pernah ditegur kerana sering bercakap sendirian. \\
30 & $\begin{array}{l}\text { Saya pernah dinasihati agar merujuk kepada pihak hospital } \\
\text { kerana berkelakuan aneh atau melakukan sesuatu yang }\end{array}$ & 0.82 & & \\
pelik. & & & \\
29 & $\begin{array}{l}\text { Saya kerap mengalami tekanan emosi yang berat dalam } \\
\text { tempoh yang panjang. }\end{array}$ & 0.77 & & \\
28 & $\begin{array}{l}\text { Saya sering mengalami fikiran yang berserabut sehingga } \\
\text { menjejaskan kewarasan tindakan. }\end{array}$ & 0.74 & & \\
25 & $\begin{array}{l}\text { Saya lebih suka bersendirian atau menjauhkan diri } \\
\text { daripada keluarga dan kawan-kawan. }\end{array}$ & & 0.87 & \\
24 & $\begin{array}{l}\text { Saya kerap mengabaikan kesihatan fizikal yang dialami. } \\
26\end{array}$ & $\begin{array}{l}\text { Saya hilang minat atau keseronokan untuk melakukan } \\
\text { aktiviti yang biasa dilakukan sebelum ini. }\end{array}$ & 0.82 & \\
22 & $\begin{array}{l}\text { Saya sering berasa bersalah memikirkan apa yang telah } \\
\text { berlaku kepada diri saya. }\end{array}$ & & & 0.79 \\
23 & $\begin{array}{l}\text { Saya pernah mengambil dadah secara berlebihan. } \\
\text { Saya kerap berasa lesu atau tidak bertenaga. }\end{array}$ & & 0.70 \\
\hline
\end{tabular}

Jadual 7: Nilai Muatan Faktor Setiap Item Bagi Komponen Putus Harapan

\begin{tabular}{llll}
\hline Item & & Komponen & \\
\cline { 3 - 3 } & & 1 & 2 \\
\hline 40 & $\begin{array}{l}\text { Saya sering berasa kematian adalah jalan penyelesaian } \\
\text { terbaik terhadap masalah hidup yang saya hadapi. }\end{array}$ & 0.87 \\
\cline { 3 - 3 } & &
\end{tabular}




\begin{tabular}{|c|c|c|c|}
\hline 36 & $\begin{array}{l}\text { Saya gagal menjalani kehidupan seperti orang lain dan } \\
\text { berasa kematian adalah jalan yang terbaik buat saya. }\end{array}$ & 0.86 & \\
\hline 37 & Saya berasa diri saya sudah lama mati. & 0.79 & \\
\hline 38 & $\begin{array}{l}\text { Saya sering membayangkan kematian apabila mengalami } \\
\text { tekanan hidup. }\end{array}$ & 0.77 & \\
\hline 35 & $\begin{array}{l}\text { Saya berasa diri saya sangat sunyi dan perlu menamatkan } \\
\text { perasaan ini dengan kematian. }\end{array}$ & 0.76 & \\
\hline 39 & $\begin{array}{l}\text { Saya lebih banyak berfikir tentang kematian berbanding } \\
\text { kehidupan pada masa hadapan. }\end{array}$ & 0.76 & \\
\hline 31 & $\begin{array}{l}\text { Saya berasa kehidupan ini sudah lama hancur dan tidak } \\
\text { dapat dipulihkan lagi. }\end{array}$ & 0.61 & \\
\hline 33 & $\begin{array}{l}\text { Saya tidak dapat mengawal hidup ini dengan baik dan } \\
\text { berasa amat sedih serta marah kepada diri sendiri. }\end{array}$ & & 0.85 \\
\hline 32 & $\begin{array}{l}\text { Saya tidak pernah berusaha untuk bangkit semula dengan } \\
\text { hala tuju kehidupan yang lebih baik. }\end{array}$ & & 0.73 \\
\hline 34 & $\begin{array}{l}\text { Saya kecewa dengan diri sendiri dan berasa amat malu } \\
\text { untuk meneruskan kehidupan ini lagi. }\end{array}$ & & 0.69 \\
\hline
\end{tabular}

Bagi memantapkan lagi pembangunan SIBA, kebolehpercayaan instrumen sekali lagi dinilai untuk melihat ketekalan dalaman dengan menggunakan pekali Alpha Cronbach. Jadual 8 menunjukkan kebolehpercayaan bagi setiap komponen instrumen SIBA selepas analisis faktor dijalankan. Hasil kajian, kebolehpercayaan ketekalan dalaman (pekali alpha) menunjukkan nilai 0.87 bagi keseluruhan komponen SIBA. Secara terperinci, Alpha Cronbach adalah 0.86 untuk konflik interpersonal, 0.86 bagi kecelaruan emosi, 0.83 kemurungan dan 0.90 untuk putus harapan. Keputusan menunjukkan, nilai kebolehpercayaan bagi setiap komponen instrumen SIBA ini dianggap boleh diterima dan sangat baik. Hal ini kerana, jika nilai alfa semakin menghampiri nilail maka lebih besar ketekalan dalaman bagi item yang telah dihasilkan. Nilai ini adalah memenuhi kehendak model pengukuran Miller et al. (2013). Nilai kebolehpercayaan responden $\geq 0.80$ adalah nilai yang sangat baik dan efektif dengan tahap konsistensi yang tinggi sesuai diguna pakai dalam kajian sebenar.

Jadual 8: Penilaian Kebolehpercayaan Kajian Sebenar Instrumen SIBA

\begin{tabular}{lll}
\hline Komponen & $\begin{array}{l}\text { Nilai } \\
\text { Kebolehpercayaan }\end{array}$ & $\begin{array}{l}\text { Interpretasi } \\
\text { Kebolehpercayaan }\end{array}$ \\
\hline Konflik Interpersonal & 0.86 & Sangat Baik dan diterima \\
Kecelaruan Emosi & 0.86 & Sangat Baik dan diterima \\
Kemurungan & 0.83 & Sangat Baik dan diterima \\
Putus Harapan & 0.90 & Sangat Baik dan diterima \\
Nilai Kebolehpercayaan Keseluruhan & 0.87 & Sangat Baik dan diterima \\
\hline
\end{tabular}

\section{Perbincangan}

Kajian ini bertujuan untuk membangunkan instrumen SIBA yang boleh dipercayai dan sah untuk mengukur tingkah laku hasrat bunuh diri dalam kalangan penagih dadah di CCRC, Besut. Terdapat 40 item untuk mengukur tingkah laku hasrat bunuh diri yang telah dikemukakan berdasarkan kajian daripada literatur, temu bual dengan panel pakar serta hasil penelitian instrumen terdahulu. Hasil semakan pakar dan analisis CVR, kesemua item dapat dikekalkan. Instrumen ini seterusnya diuji kepada 123 responden iaitu penghuni di CCRC, Besut. Hasil daripada ujian analisis faktor yang dilakukan, instrumen akhir SIBA terdiri daripada 40 item dipecahkan kepada 4 komponen iaitu konflik interpersonal (10 item), kecelaruan emosi (10 item), kemurungan (10 item) dan putus harapan (10 item). Instrumen SIBA ini menunjukkan kebolehpercayaan yang tinggi dan juga kesahihan komponen yang cukup baik. Oleh itu, instrumen ini boleh digunakan dalam menilai tahap tingkah laku hasrat bunuh diri ini. Keputusan ini mengesahkan kesemua item adalah sah diguna pakai dalam menjalankan kajian sebenar manakala nilai kebolehpercayaan instrumen adalah sangat baik dan efektif dengan konsistensi yang tinggi. Tambahan pula, instrumen ini juga mempunyai kelebihan tersendiri iaitu mudah 
ditadbirkan dan dijawab oleh responden dengan terdiri daripada 4 Likert skala. Selain itu juga, instrumen SIBA ini adalah mesra pengguna; tatabahasa dan perkataan yang digunakan adalah ringkas dan mudah difahami. Tambahan pula, ia juga sangat ekonomikal dari segi masa dan kecekapan kos. Walau bagaimanapun, perhatian perlu diambil dalam pembinaan dan pengesahan, kerana penubuhan instrumen ini direka untuk penagih dadah sebagai responden. Oleh itu sebarang penambahbaikan perlu ada dari semasa ke semasa supaya penggunaannya adalah bererti.

\section{Kesimpulan}

Pembangunan dan pengesahan Soal Selidik instrumen SIBA telah mengambil kira semakan pakar dalam bidang berkenaan dan disokong dengan hasil analisis. Keabsahan dan kebolehpercayaan instrumen yang dibangunkan membuktikan instrumen yang dihasilkan ini merupakan suatu alat kajian yang mempunyai kesahan dan kebolehpercayaan yang tinggi. Oleh itu, kajian ini dapat menunjukkan bahawa instrumen yang dibina ini boleh diguna pakai untuk mengukur tahap tingkah laku hasrat bunuh diri dalam kalangan penagih dadah yang sedang menjalani rawatan di pusat pemulihan tersebut. Pada masa akan datang, instrumen ini dicadangkan agar menjalani beberapa siri ujian lagi untuk memastikannya menjadi satu instrumen yang lebih berkesan dan berguna dengan keperluan semasa. Instrumen SIBA yang dibina ini diharapkan dapat memberikan sumbangan yang besar kepada kerajaan terutamanya CCRC dalam usaha membantu penagih yang mempunyai tingkah laku hasrat bunuh diri untuk diberikan perhatian dan perkhidmatan sokongan psikososial yang lebih baik.

\section{Rujukan}

Alloy, L. B., Black, S. K., Young, M. E., Goldstein, K. E., Shapero, B. G., Stange, J. P., Abramson, L. Y. (2012). Cognitive Vulnerabilities and Depression Versus Other Psychopathology Symptoms and Diagnoses In Early Adolescence. Journal of Clinical Child \& Adolescent Psychology, 41: 539-560.

Bao, Y., Zhu, F. , Hu, Y. and Cui, N. (2016). The Research Of Interpersonal Conflict And Solution Strategies. Psychology, 7: 541-545.

Bilsen, J. (2018). Public Mental Health. Suicide and Youth: Risk factors. Front.Journal of Psychiatry, 9: 540.

Buchman-Schmitt, J. M., Chu, C., Michaels, M. S., Hames, J. L., Silva, C., Hagan, C. R. (2017). The Role of Stressful Life Events Preceding Death by Suicide: Evidence From Two Samples of Suicide Decedents. Psychiatry Research, (256): 345-52.

Boduszek, D., \& Dhingra, K. (2016). Construct Validity Of The Beck Hopelessness Scale (Bhs) Among University Students: A Multitrait-Multimethod Approach. Psychological Assessment, 28(10): 1325- 1330.

Bond, T. G., \& Fox, C. M. (2015). Applying The Rasch Model Fundamental Measurement In The Human Sciences. (Routledge \& T. \& T. \& F. Group, Eds.) (Third Edit). New York \& London.

Brent, D. A. (1995). Risk Factors For Adolescent Suicide And Suicidal Behavior: Mental and Substance Abuse Disorders, Family Environmental Factors, and Life Stress. Suicide Life Threat Behavior, 25: 52-63.

Briere, F. N., Fallu, J-S., Janosz, M. \& Pagani, L. S. (2012). Prospective Associations Between Meth/Amphetamine (Speed) and MDMA (Ecstasy) Use and Depressive Symptoms In Secondary School Students. Journal Epidemiol Community Health, 66(11): 990-4.

Conner, K., Bagge, C., Goldston, D., \& IIgen, M. (2014). Alcohol And Suicidal Behavior: What Is Known And What Can Be Done. American Journal of Preventive Medicine, 4: 204-208.

Creswell, J. W., \& Plano Clark, V. L. (2011). Designing and Conducting Mixed Methods Research (2nd ed.). Thousand Oaks, CA: Sage.

David, N., Miller \& Tanya, L., Eckert. (2009). Youth suicidal behavior: An introduction and overview. School Psychology Review, 38:153-167.

Dragisic, T., Dickov, A., Dickov, V., \& Mijatovic, V. (2015). Drug addiction as risk for suicide attempts. Materia Socio-Medica, 27(3): 188-191. 
Evren, C., Cinar, O., Evren, B \& Celik, S. (2011). History of suicide attempt in male substancedependent inpatients and relationship to borderline personality features, anger, hostility and aggression. Psychiatry Research, 190(1): 126-31.

Fraenkel, J.R., \&Wallen, N. E. (2009). How to design and happiness. Journal of Contemporary Religion, 12(1): 81-86.

Fraenkel, R. J., \& Wallen, N. E. (2006). How to Design And Evaluate Research In Education. 6th Ed. McGraw-Hill: Boston.

Inman, D., van Bakergem, K., LaRosa, A., \& Carr, D. (2011). Evidence-based health promotion programs for school and communities. American Journal of Preventive Medicine, 40, 207-219.

Jenny, M. Y. H., Brian Y.T., Samuel, M.Y., Paul, S. F. (2015). Hope and Hopelenessnes: The role of hope in buffering the impact of hopelessness on suicidal ideation. Journal of Plos One, 10 (6).

Kaiser, H. (1974). An index of factorial simplicity. Psychometrika, 39: 31-6.

Gallagher, M. L., \& Miller A. B. (2018). Suicidal thoughts and behavior in children and adolescents: an ecological model of resilience. Journal of Adolescent Research, 3: 123-154.

Ghaffari, J., Mohammadzadeh, I., Khalilian, A., Rafatpanah, H., Mohammadjafari, H., \& Davoudi, A. (2012). Prevalence of asthma, allergic rhinitis and eczema in elementary schools in Sari (Iran). Caspian Journal of Internal Medicine, 3(1), 372-376.

Global Burden of Disease Collaborative Network. (2018). Global Burden of Disease Study 2017 (GBD 2017) Results. Seattle. United States: Institute for Health Metrics and Evaluation (IHME).

Hair, J. F., Anderson, R. E., Babin, B. J. \& Black, W. C. (2010). Multivariate Data Analysis: A global Perspective (Volume 7). England: Pearson.

Jager-Hyman, S., Cunningham, A., Wenzel, A., Mattei, S., Brown, G. K., \& Beck, A. T. (2014). Cognitive distortions and suicide attempts. Cognitive Therapy and Research, 38(4): 369-374.

Lam, W.M. (2014). In their own words: Perceived experiences and family functioning of suicide survivors before and after suicide loss. PCOM Psychology Dissertations. Paper 308.

Lima, D. D., Azevedo, R. C. S., Gaspar, K. C.., Silva, V. F., Mauro, M. .L. .F., \& Botega, N. J. (2010). Suicide attempt amongst patients with alcohol misuse admitted to a general hospital. Brazillian Journal of Psychiatry, 59(3): 167-172.

Lliceto, E., \& Fino, E. (2015). Beck Hopelessness Scale (BHS). A Second-Order Confi rmatory Factor Analysis. European. Journal of Psychological Assessment, 31(1): 31-37.

Miller. A.L., Mcintre, A.S., \& Lovler, L.R. (2013). Foundations of Psychological Testing: Practical Approach (4th Ed.). California: SAGE Publications.

National Survey of Drug Use and Health. (2018). The NSDUH Report: Suicidal Thoughts and Behaviours Among Adults. Rockville, MD: Substance Abuse and Mental Health Services Administration.

Oquendo, M. A., \& Baca-Garcia, E. (2014). Suicidal behavior disorder as a diagnostic entity in the DSM-5 classification system: Advantages outweigh limitations. MWorld Psychiatry, 3(2): 128130.

Pallant. (2010). SPSS Survival Manual A Step by Step Guide to Data Analysis using SPSS for Windows ,4rd Edition, Crows West: New South Wales.

Pedrelli, P., Iovieno, N., Vitali, M., Tedeschini, E., Bentley, K. H., \& Papakostas, G., I. (2011). Treatment of major depressive disorder and dysthymic disorder with antidepressants in patients with comorbid opiate use disorders enrolled in methadone maintenance therapy: A meta-analysis. Jounal of Clin Psychopharmacol, 31(5): 582-6.

Quilty, L. C., Mainland, B. J., McBride, C., \& Bagby, R. M. (2013). Interpersonal problems and impacts: Further evidence for the role of interpersonal functioning in treatment outcome in major depressive disorder". Journal of Affective Disorders, 50: 393-400.

Sawaya, H., Johnson, K., Schmidt, M., Arana, A., Chahine, G. \& Atoui M. (2015). Resting-state functional connectivity of antero-medial prefrontal cortex sub-regions in major depression and relationship to emotional intelligence. International Journal of Neuropsychopharmacology, 18: $1-9$.

Schutte, N. S., Malouff, J. M., Thorsteinsson, N. B. \& Rooke S. E. (2007). A meta-analytic investigation of the relationship between emotional intelligence and health. Personality and Individual Differences, 42: 921-933. 
Substance Abuse and Mental Health Services Administration. (2015). NSDUH Data Review. Suicidal Thoughts and Behavior Among Adults: Results from the 2014 National Survey on Drug Use and Health.

Taylor \& Jacqueline. (2018) Illegal Drug Use, Suicidal Ideation, and Attempted Suicide Among New York Adolescents. Walden Dissertations and Doctoral Studies, 5663.

Ugwuoke, A. C. (2016). Precipitants of suicide among secondary school students in Nigeria. Bassery Andah Journal, 9: 147-156.

United Nations Office on Drugs and Crime (UNODOC). (2014). World Drug Report. Viena: United Nations Office on Drugs and Crime.

Van Orden, K. A., Witte, T. K., Cukrowicz, K. C., Braithwaite, S. R., Selby, E. A., \& Joiner, T. E. (2010). The interpersonal theory of suicide. Psychological Review, 117: 575-600.

Wong, S.S., Zhou, B., Goebert, D., Hishinuma, E.S., (2013). The risk of adolescent suicide across patterns of drug use: a nationally representative study of high school students in the United States from 1999 to 2009. Soc. Psychiatry Psychiatr. Epidemiol. 48: 1611-1620.

World Health Organization. (2017). Global Health Observatory. Retrieved from http://www.who. int/gho/mental_health/suicide_rates/en

World Health Organization. (2019). Thirteenth General Programme of Work, 2019-2023: Promote Health Keep The World Safe Serve The Vulnerable. Geneva: WHO.

Youssef, Ismail \& Haggag, Wafaal \& Mohamed, Khaleda \& Baalash, Amany. (2016). "Dual diagnosis and suicide probability in poly-drug user". Journal of the College of Physicians and SurgeonsPakistan JCPSP, 26: 130-133. 